\title{
ARTICLES
}

\section{Why the where matters A sense of place imperative for teaching better Indigenous affairs reporting}

\begin{abstract}
Much Indigenous affairs journalism in the Western Australian state capital of Perth reproduces colonial discourse and perpetuates racist stereotypes of Aboriginal people. Against this background the traditional custodians of Perth, the Noongar people, have struggled to find a media voice. Meanwhile, observers in several countries have critiqued a shift from journalism about specific places toward journalism concerned with no place in particular. Spurred by globalisation, this shift has de-emphasised the 'where?' question in the 'what, where, who, why, how and when?' template of journalistic investigation. Reporting from a project in which journalism students collaborated with Noongar community organisations, we argue that an understanding of Indigenous Australians' profound connection to place can inform journalists about the underlying character of places about which they report. We suggest that working with Indigenous people can transform the way journalists conceptualise their careers, and help secure a sense of place for Indigenous people in the media. Finally, collaborating with Indigenous people can teach journalists to view their professional practices through a sense of place lens, re-emphasising the 'where?' question in its application to both geographic place and the realm of a journalist's imagination.
\end{abstract}

Keywords: Aboriginal affairs journalism, action research, Australia, habitus and place, higher education teaching and learning, Indigenous affairs journalism, Indigenous media collaboration, Indigenous media representation, Indigenous voice, Pierre Bourdieu, Noongar voice, sense of place, service learning, SOTL

\section{CHRIS THOMSON, DAWN BENNETT, MICHELLE JOHNSTON and BONITA MASON Curtin University, Wadjuk Noongar country (Perth)}

$\mathrm{N}$ this largely theoretical article we argue that placeless representation can, through exposure to the place-based reality of Indigenous people, be transformed into placebased representation that repositions the 'where?' question back at the centre of journalistic investigation and practice. Reporting from a project that partnered six journalism students with four Indigenous community organisations to produce stories that were published online, we explore how independent journalism in the context of collaboration with Indigenous sources can achieve a more authentic articulation of place at three 
levels: by achieving more inclusive representations of the places on which journalists report; at the level of journalists' evolving practices (or their sense of place in the journalistic field); and by helping to lever a sense of place for Indigenous people in the media.

Initiated at Curtin University, the project became known by participants as Aboriginal Community Engagement, or ACE. In this article we position ACE within the context of calls to embed Indigenous perspectives into tertiary education. We follow with a critique of Indigenous affairs reporting in Perth and a project rationale that recognises the leading role of Perth's Noongar people in the struggle for Aboriginal land rights in Australia's capital cities. We then describe the pedagogical framework for ACE, following this with a review of literature on the potential for Indigenous sense of place to inform reconciliation between Australia's Indigenous and non-Indigenous people. Recognising the broader context of this work, analyses that apply sense of place theory to the practice of text-based journalism are considered. Several of these analyses critique a globalised-era shift from journalism about specific places, to journalism concerned with no place in particular-a trend that has marginalised the 'where?' question in the 'what, where, who, why, how and when?' template of journalistic investigation.

Beyond this important reinstatement of 'where?' as it applies to geographic place (that is, the context in which 'where?' is normally understood), we illustrate how collaboration with Indigenous sources can teach journalists to view their professional practices through a sense of place lens. In order to apply the concept of place to professional practice, we draw parallels between sense of place theory and two other theoretical constructs: the conceptual tool of habitus advanced by French sociologist Pierre Bourdieu; and studies that address Indigenous media voice.

\section{Background}

\section{Indigenous perspectives in higher education}

In 2009, the National Indigenous Higher Education Network (NIHEN, p. 7) recommended in its report to the United Nations that tertiary institutions should "systemically embed Indigenous perspectives in curriculum and acknowledge the scholarly contributions of Indigenous communities in developing a culturally ethical framework to underpin research and learning". In Australia, the most comprehensive move toward this end was Universities Australia's (2011) framework 'for embedding Indigenous cultural competencies within and across the institution in sustainable ways which engender reconciliation and social justice by enabling the factors that contribute to social, economic and political change'. The framework is premised upon five guiding principles, two of which are crucial to ACE:

- All graduates of Australian universities will have the knowledge and skills necessary to interact in a culturally competent way with Indigenous communities; and

- Universities will operate in partnership with their Indigenous communities and

142 PACIFIC JOURNALISM REVIEW 21(1) 2015 
will help disseminate culturally competent practices to the wider community. (p. 8)

Many Australian universities have responded by embedding Indigenous culture and intercultural competency across curricula and incorporating Indigenous cultural competency within their graduate attributes. Newsome (1999), however, has highlighted the limitations of such initiatives if they are removed from the lived experience of Indigenous culture and traditional Indigenous protocols for sharing knowledge. Such abstract learning can lack the intercultural relationships required to promote reconciliation and deeper understanding of Indigenous ways of seeing and being (Mackinlay \& DunbarHall, 2003). Against this background, service learning has emerged as a valuable tool for community engagement and the advancement of the civic mission to create wellrounded graduates and constructive change (Winter, Wiseman \& Muirhead, 2006).

The service learning project described here was initiated by two lecturers in the field of text-based journalism, one screen arts lecturer, and a project leader with an arts education background. We chose to work in partnership with Perth's Noongar people for five main reasons. First, Noongar people are the traditional custodians of the land now occupied by Curtin University. Second, although Noongar people are the only Aboriginal people in Western Australia to have seen a metropolis rise on their traditional lands, and were the first in the state to face the brunt of colonialism, major elements of their traditional culture remain. Third, the Noongar community is the largest Aboriginal nation by population in Western Australia (Department of Aboriginal Affairs, 2013). Fourth, the Noongar nation has continued to struggle to establish a media voice (see, for example, Kerr \& Cox, 2013). Fifth, we wanted to create relationships with local Noongar people so that students might begin to see them as part of their own community.

\section{Noongar people, media voice and media misrepresentation}

In 2011 an estimated 88,270 Aboriginal and Torres Strait Islander people lived in Western Australia (Australian Bureau of Statistics, 2013), making up 3.8 per cent of the Western Australian population. This equated to 13.2 per cent of Australia's total Indigenous population and was the third largest Indigenous population of any Australian state or territory. The Noongar Aboriginal people are the traditional custodians of south-western Australia, a 242,000 square kilometre (South West Aboriginal Land and Sea Council) corner of the continent that, in terms of area, is roughly the size of New Zealand. Noongar country includes metropolitan Perth and extends from north of the town of Jurien Bay, 220km north of Perth on Australia's west coast, to east of Hopetoun on Australia's south coast. The area is home to 14 distinct Noongar groups. Members of one of those groups, the Wadjuk Noongar people, are the traditional custodians of metropolitan Perth.

Our project was located in metropolitan Perth, which in 2011 was home to 32,836 people who claimed Indigenous heritage (Australian Bureau of Statistics, 2013). In 2013 
the Western Australian Department of Aboriginal Affairs estimated that 34,600, or 39.2 percent, of the state's Indigenous people lived in metropolitan Perth and the 20 surrounding local government areas. These areas lie mainly in Noongar country (Department of Aboriginal Affairs, 2013).

At the time of writing, several decade-long native title claims over south-western Australia, including Perth, had only recently been settled. In a summary accompanying his September 2006 interim decision on those claims, Justice Murray Wilcox concluded that 'the contemporary Noongar community acknowledges and observes laws and customs relating to land which are a recognisable adaptation to their situation of the laws and customs existing at the [1829] date of settlement' (Bennell v Western Australia, 2006). He noted that:

The Noongar community was enormously affected by white settlement. Aboriginal people were forced off their land and dispersed to other areas. Families were broken up. The descent system was affected by the fact that many children were fathered by white men. Probably in every Noongar family there is at least one white male ancestor. Over a long period, mixed-blood children were routinely taken away from their parents. Notwithstanding all this, and surprisingly to me, members of families seem mostly to have kept in contact with each other, and families with other Noongar families. Many, if not most, children learned at least some Noongar language. Many, if not most, were taught traditional skills, such as for hunting, fishing and food-gathering, and learned traditional Noongar beliefs, including in relation to the spirit world.

Justice Wilcox found that the Noongar people held native title over some parts of the land and waters within Perth (National Native Title Tribunal, 2006). This interim judgment was the first to recognise native title over an Australian capital city.

In the immediate wake of the judgment, much speculation ensued, nationally, about where native title might apply in Australia's capital cities. Federal Attorney-General at the time, Phillip Ruddock, claimed that the ruling would have 'significant' implications for Australia's capital cities (cited in Peatling, 2006), where public access to beaches and parks might no longer be guaranteed (Guest, 2006). In October 2006, the National Native Tribunal moved to allay such fears by publishing a newsletter that stated:

In the context of the metropolitan area, there might be very small pockets of unallocated crown land and some reserve land where native title rights and interests may have survived. However, even over areas where native title is found to have survived, where others have rights and responsibilities over the same area (including public rights), the law gives their rights priority over native title. Existing public access and enjoyment of public places such as beaches, parks, waterways and foreshores is protected by state legislation that confirms that access continues. (National Native Title Tribunal, 2006)

144 PACIFIC JOURNALISM REVIEW 21(1) 2015 
This struggle over land demonstrates that sense of place is complex and contested. On appeal by the Western Australian government and other parties, the Full Bench of the Federal Court in 2008 held that Justice Wilcox had failed to consider whether there had been continuous acknowledgment and observance of traditional laws and customs by the claimants from 1829 until recent times. The Full Bench also questioned whether the claimants had a connection with metropolitan Perth as opposed to the wider claim area (Bodney v Bennell, 2008). It left the question of native title in Perth open for further consideration.

In 2009, State Cabinet decided the Western Australian government would abandon its legal challenge and instead negotiate direct with the Noongar people (Thomson, 2009) and, in 2013, the State government presented the South West Aboriginal Land and Sea Council (the native title representative body for the Noongar people) with a 'final offer' to surrender the claims (Barnett \& Mischin, 2013) in exchange for what the state Premier Colin Barnett asserted was ' $\$ 1.3$ billion in land and other assets and benefits' (Barnett, 2015). Following 'exhaustive negotiations' (Barnett, 2014), in March 2015, a vote of the Noongar community arranged by the South West Aboriginal Land and Sea Council agreed to accept the government's offer. The offer included a promised Act of Parliament recognising Noongar people as traditional owners of the state's Southwest.

This background, which outlines something of the scope and depth of the Noongar connection to place, also connects to voice - who is heard in the media and how they are heard and represented. The extent to which the Noongar voice is, or is not, adequately represented by Perth's big media organisations was demonstrated quite recently by the coverage of the Noongar 'tent embassy' established in 2012 at Matagarup (Heirisson Island), which is located not far from Kooraree (the grounds of Government House near the Perth CBD) (Aboriginal place names from Hughes-Hallett, 2010). Kerr and Cox's analysis of reports by big media corporations during the embassy's six-week presence at Matagarup concluded that, with few exceptions, the embassy was depicted as an illegal, menacing 'Aboriginal protest camp' (2013, p. 5). This representation, and selective reporting practices, were considered to have legitimised repeated police raids on Noongar people who had gathered for discussions on native title at a state-listed Aboriginal heritage site (2013, p.5).

Although Perth is the fourth largest city in Australia, the reporting of the Noongar Tent Embassy is but one indicator of a poor standard of Indigenous affairs journalism more akin to the city's onetime position as a remote colonial outpost. For other examples, see the Western Australian underlying issues volume (section 18) of the final report of the Royal Commission into Aboriginal Deaths in Custody (RCIACIC, 1991); and Donovan, Wilkes, Fielder and Jalleh's 2013 study of The West Australian newspaper's refusal to accord due prominence to the publication of an Australian Press Council finding of misleading material in a front-page story about an Aboriginal man. 
These examples and analyses illustrate and explain the often poor relationship between big media corporations and Aboriginal people in Western Australia. Further insight emerged from a 2013 panel discussion following a lecture given by former Media Watch host Jonathan Holmes at Curtin University. During the discussion, The West Australian's editor-in-chief, Bob Cronin, told an audience of 400 people that in his experience positive journalism stories about Aboriginal people, especially on the front page and with an accompanying photograph, were usually followed by a slump in newspaper sales (Cronin, 2013). An indication of the prominence The West Australian now places on Indigenous affairs reporting is that, for the past several years, the newspaper has had no specialist Indigenous affairs reporter.

Such structural impediments to good Indigenous affairs reporting are nothing new in Western Australia, and we do not wish to suggest there are no good Indigenous affairs reporters in the state. In 1992, for example, a former Western Australian correspondent for Australian Associated Press observed that despite harassment by authorities, some Western Australian journalists continued to write stories about Aboriginal deaths in custody because of a belief the public should know how Aboriginal people were being treated by the law, police, courts and government (Plater, 1993, p. 203). Such journalists still practise in Western Australia.

One of the aims of our work through the ACE project was to increase the stock of such Indigenous affairs reporters in Western Australia. The project was informed by previous work integrated learning projects, including: the Curtin University Noongar Dandjoo television series (documented in Johnston \& Bishop, 2013); a collaboration between academics, journalism students and Indigenous media participants in Queensland (documented in Stewart, et al, 2010); and the placement of Edith Cowan University journalism students with Aboriginal communities in two Western Australian towns (documented in Cullen, 2010).

Much work has been done elsewhere in the Pacific to encourage engagement between journalism students and Indigenous and local communities, with social justice objectives in mind. The award-winning work of students from the University of the South Pacific in reporting the Fiji coup in 2000 (documented in Cass, 2002, and Robie, 2001, 2010), and efforts at Divine World University in Papua New Guinea in the early 2000s to reorient the journalism programme there toward 'social justice and the need to provide a voice for the voiceless, while holding the powerful to account' (Rooney, 2003, p. 76), are two notable examples.

\section{The ACE Approach}

ACE was part of a broader Australian National Office for Learning and Teaching-funded project to establish service learning projects with Indigenous communities at three Australian universities (Bartleet, Bennett, Power \& Sunderland, 2014). The project was intensive, involving 13 students who were undertaking online journalism, journalism

146 PACIFIC JOURNALISM REVIEW 21(1) 2015 
feature writing, and screen studies units. Most students were in their second or third year of undergraduate study, one was undertaking her honours year and another was in the first semester of a Graduate Diploma in Journalism. As this article's focus is on journalism education it reports on the work of the six text-based journalism students. The students, all of whom were young women, worked to source, research, write, photograph and produce stories in the context of a relationship with Noongar sources, but as independent journalists.

\section{Theoretical framework}

We adopted a post-colonial approach to explore 'alternative possibilities to the forces of colonisation' via 'hybrid historical productions' (Somerville \& Perkins, 2003, p. 255), by:

- recognising and reconceptualising categories which maintain borders, for example, Indigenous/non-Indigenous (Giroux, 1992);

- acknowledging hybrid subject-positions, for example, 'temporal and contextual coalitions' (Haig-Brown, 2001) or the 'third space' (Soja, 2000);

- redrawing boundaries between constructions of experience and power (Giroux, 1992); and

- questioning who has a right to speak and what is appropriate in particular contexts at particular times (Mackinlay, 2008).

One of Bourdieu's main conceptual tools, habitus, allows for the position of a social actor - in this case, a member of an Aboriginal community group, a student or lecturer-in a field of practice, such as journalism, to be identified and considered. Habitus, as a set of dispositions, represents a practitioner's internalised history (Wacquant, in Bourdieu \& Wacquant, 1992, p. 16) and, as a relational concept, is about how practitioners see themselves and other people, and therefore how they practiSe, within a field (Mason, 2014, p. 166). It is therefore capable of taking account of and explaining categories and where the boundaries are drawn, hybrid subject-positions and context, and power relations - features of the post-colonial approach set out above. Importantly, when considered in terms of Noongar people's lack of media voice, habitus provides a platform from which to theorise the position and voicelessness of people dominated and disadvantaged by existing power relations (Mason, 2014, p. 165).

To enable the intercultural interactions envisaged by the post-colonial approach outlined above, we employed service learning to enrich student learning while strengthening communities (Furco, 1996), and to provide transformative social and personal experiences (Robinson \& Meyer, 2012). ACE focused on authentic relationships, social change and power redistribution, and encouraging students to critically question broad academic and journalistic discourses.

ACE combined service learning with 'participatory action research', which creates positive change through action and change that results in action. Action researchers often refer to themselves as facilitators who work with community organisations, members of 
which participate not as subjects but as co-researchers 'in the production of knowledge through rigorous, well-planned, structured and self-aware methods' (Tacchi, Slater \& Hearn, 2003, p. 13). Better described as a philosophy than a methodology, action research is a democratic and inclusive way of working that recognises the life experience and knowledge of community participants. For a full description of the action research approach employed in ACE, see Johnston, et al (2015).

\section{Structure}

A call for expressions of interest nominated pre-requisites that ensured the students had sufficient skills to complete story-based projects (interviewing, writing and production skills, for example). Journalism students enrolled in one of two journalism units, undertaking a blend of subject-specific and service learning tasks. For the usual story production components of the journalism units, students were required to produce Indigenous affairs stories emerging from their collaboration with Noongar people. Action research allowed a primary focus on the process of creating stories rather than on the product each student was required to submit for assessment. There was an emphasis on taking time to listen and talk to, and establish relationships with, community partners.

Before their involvement in ACE, only two of the six students had engaged with Indigenous people or culture to any great degree. During the first month of semester, four three-hour workshops introduced the students to action research and Noongar culture and history. An action research expert and three Noongar people with backgrounds in the creative industries played leadership roles in each of those workshops. The project team involved all participants in regular readings and guided reflections.

Along with the students, we attended a day-long field trip led by then director of Curtin University's Centre for Aboriginal Studies, and Noongar Elder, Associate Professor Simon Forrest. The field trip retraced the 1834 journey of Western Australia's first governor, James Stirling, and about 25 police officers, soldiers and settlers who, on a punitive raid from central Perth to Pinjarra, 86 kilometres to the south, killed an estimated 14 to 30 men, women and children of the Bindjareb group of the Noongar nation (Stasiuk, 2015). The massacre was a watershed moment in the shared history of Noongar people and people of European descent (Forrest, 2014). Participants in the field trip paid respect to lives lost and heard Simon Forrest call for a shared understanding of Australian history. By imparting aspects of the largely hidden Noongar history of well-known sites along modern-day Stirling Highway, and beyond to Pinjarra, the field trip introduced students to the theory of contested sense of place as advanced in Wadjuk Noongar country by scholars including Cox (2012).

We used existing networks to ask local Indigenous organisations whether there was anything to which the students might feasibly contribute. This led to several project ideas that were matched with the timeline of ACE and the capabilities of students and lecturers. Student projects were initiated with four community organisations - the Langford 
Aboriginal Association (which runs programmes related to culture, health and wellbeing), Indigenous Community Engagement and Awareness (a youth-run reconciliation and community awareness foundation), Kart Koort Wiern (an Aboriginal reconciliation and cultural awareness training consultancy), and the Wirrpanda Foundation (which aims to empower and build capacity among Indigenous people).

In collaboration with each group and their participants, students produced in-depth stories that formed the backbone of a new Aboriginal affairs reporting round on Curtin University's InkWire journalism website (inkwirenews.com.au/category/aboriginalaffairs/). The journalism teaching technique of simulating a deadline-driven newsroom, in which students are required to extract stories from sources in a compressed timeframe, was deliberately inverted so that students could concentrate on stories that their Indigenous sources were willing to share. Each student visited their community group many times for several hours at a time, and the focus was on building genuine relationships before story sourcing commenced.

At the end of semester, students displayed their stories at a public showcase. The showcase gave a voice to Aboriginal community participants and to students, who publicly reflected upon ACE and its impact. It also provided an opportunity for partners, students, senior university leaders, academics and members of the public to engage in the learning that emerged from the project and to celebrate the results of the students' hard work.

\section{Data collection and analysis}

Once ethical approval had been secured, data collection involved semi-structured interviews, student assessment and reflection, documentation of researcher reflections, short pre- and post-surveys, and analysis of student and community partner reflections at the public showcase. Analysis incorporated inductive independent coding (Janesick, 2000) by two members of the research team, after which coding was compared to create a final codebook. The voices included in this paper are derived from interviews, and public statements made by participants at the showcase.

\section{Discussion and findings}

This section presents our research and learning in relation to what Indigenous Australians can teach non-Indigenous Australians about the underlying character of places, and how consideration of Indigenous perspectives of place might positively influence Australian culture. We provide an overview of literature across three continents that considers the practice of journalism from a sense of place perspective. Parallels are drawn between sense of place theory and the Bourdieusian concept of habitus to demonstrate how an understanding of Indigenous sense of place can inform and transform the professional practices of journalists, by imparting a better understanding of their place and the place of others in the journalistic field. Drawing on student feedback, we conclude by considering the practical implications of this for journalism education and practice. 


\section{Indigenous sense of place and journalism}

Guffey (2008, p. 2) ties together the practice of service learning, the journalistic mainstay of storytelling, and the concept of place by describing the building of:

a 'strong link' from indigenous ways, the earth and nature into the larger society. ... I ask the question: how do people learn to find and know themselves in this world? The answer that I have come to is two-fold: first, by encountering and establishing spiritual connections with the earth through the senses, the intellect and the emotional body. Second, through the inter-relationship of storytelling and service learning. Think of storytelling as a needle and service learning as the thread. The story makes an impression and creates an opening, then service learning follows. Together they draw the fabric of life: people, places and nature together in new experiences.

Far from the dominant, Westernised construction of space, for Australian Aboriginal people:

country is sentient, country has agency. Country assumes the social form of persons. Indeed, country is inhabited by various other-than-human persons, and it is these beings, and their traces (which are consubstantial with the beings), that vest the country with such sentience. (Glaskin, 2012, p. 305)

While cautious of generalising across Australia's 500-plus Indigenous nations, Rapoport (1972, 3-3-8) notes that Aboriginal people do not 'move just in a landscape but in a humanised realm saturated with significations', and put great importance on the naming of places. The importance of place names is one aspect of a sense of place that is especially pertinent in south-western Australia which has the largest proportion of preserved Indigenous place names of any region nationally - with more than 50 percent of the currently used names being of Noongar origin (Collard, et al., 2011, p. 1). Collard, et al. (2011, p. 7) observe that while relationships between colonisers and Indigenous Australians have been vexed, the preservation of Noongar place names resulted from crosscultural collaboration of the kind that could inform and enrich the future of Australia. Plumwood (2005, p. 386) sees a return to Indigenous place names as a form of 'deep republicanism' that respects 'the uniqueness and power of place as well as recognising its prior naming and occupation by Aboriginal people'.

For Birrell (2006, p. ix), 'the integration of an Aboriginal worldview in non-Indigenous persons may [already] be leading towards the development of a new sensitivity that connects [non-Indigenous people] with place, more informed by Indigenous ways of being'. Plumwood agrees: there are 'many good reasons to conclude that a rich, deep connection with land and place is a key part of a healthy human culture' $(2005, \mathrm{p}$. 371). She continues:

There is much to be said for working for cultural convergence, to evolve what Aboriginal philosopher Mary Graham ... calls 'the embryonic form of an intact,

150 PACIFIC JOURNALISM REVIEW 21(1) 2015 
collective spiritual identity for all Australians, which will inform and support our daily lives, our aspirations and creative genius'. (p. 371)

While the geographical places in which the students sourced their stories were often familiar to both the students and the organisations with which they worked, the meanings and connections of each place were vastly different for Indigenous and non-Indigenous participants. Reinterpreting their relationship with Perth represented one of the greatest challenges for the students. It was also the source of far deeper cultural understandings and friendships between students, lecturers and community participants. Feedback from one participating student is salient:

I remember the first time I arrived [at the premises of the Indigenous community group]. It just looked so empty and I'd never been to the suburb, anywhere near there. I was just like: 'Oh'. As soon as I walked in it was fine. As soon as you walk in there and all those ladies are just sitting around that table laughing, it's a warm environment. (Student 4)

Oddly, for a profession where practitioners are taught to answer the main 'where?' question in every story they write, a literature search of the English speaking world confirms that in the years since Griffin (1999, p. 17) noted a dearth of 'commentators who have considered the role of place in journalism', text-based journalism has largely avoided the gaze of sense of place researchers, except to a nascent extent in North America, the United Kingdom and Australia.

North American observers have delineated and critiqued a shift from journalism about local places toward journalism of a regional, national or international scale, or that focuses on no place in particular (for example, Buchanan, 2009; Funk, 2012; Walrus Research, 2006). In part, this shift is a natural extension of a trend recognised since at least the mid-1980s (Meyrowitz, 1985) in which electronic media were seen to intrude into private and local places, and to erode the uniqueness of those places. Buchanan's (2009, p. iii) analysis of two Canadian newspapers attributes the shift to, among other factors, rising corporate influence on newspaper priorities and a gradual process that appears to favour the national and global over the local. In the United States of America also, a transformation from local to national and international ownership of mainstream news media has been shown to play a part (Pauly \& Eckert, 2002). Funk adds to this discussion by making the point that: 'In the online era, it seems newspapers are principally concerned with the business of being a newspaper-not of being a community entity or a local organisation' (2012, p. 584).

Buchanan also notes that the shift from local to more geographically generic journalism has posed a direct challenge to the prominence of the 'where?' question in the 'who, what, where, when, why and how?' template that has long been the foundation for journalistic investigation (2009, p. 16). The experienced and multiple-award winning 
journalist Robert Fisk (2014) has criticised one manifestation of this shift as inaccurate and disrespectful, the now common practice of publishing geographically generic news photographs to illustrate stories about specific occurrences in specific places.

A survey of public radio audiences in the USA reveals a perception that metropolitan daily newspapers lack quality and quantity of local coverage (Walrus Research, 2006, p. 6). In another study, Pauly and Eckert note that, although keywords that journalism uses to describe itself, such as 'independent', 'public' and 'objective', have been thoroughly studied, the term 'local' has escaped similar scrutiny in the USA. Yet, they also argue that the 'myth of the local has been equally as rich and potent' (2002, p. 2).

In the United Kingdom, analysis has focused less on sense of place and more on the related concept of localism. In one example, Harcup documents the demise of the alternative local newspaper - a phenomenon of the 1970s, 1980s and early 1990s - in the United Kingdom. He concludes that 'the discernible irony is that the demise of these newspapers coincided with the arrival of computers and desktop publishing technology which might have made their production cheaper, quicker and less labour-intensive' (1998, p. 115).

In Australia, a decade-and-a-half later, and with the enabling power of software and personal computers multiplied by mass access to the internet, Richardson (2012, p. 123) notes that 'metropolitan media has finally realised that the local stories that are the staples of community media are the fuel that drives the digital engines of contemporary media'. For Richardson, 'the cornerstone of this localism is its capacity to deliver and engage audiences in a way that offers opportunities to build loyalty and potentially create a new kind of revenue model' (p. 123). He argues that 'the advent of online news has delivered community newspapers a combined paper-online audience that is greater than ever' (p. 124).

Richardson's analysis is insightful in delineating a potential pendulum-swing back to localism and, through that, implicitly to the fluid nature of interactions between publications and audiences over time. However, his analysis is problematic because, with the exception of a passing observation about locally owned newspapers, it focuses on the majority of the nation's local newspapers that in their ownership structure have nothing to do with being local. Richardson rightly notes $(2012$, p. 127) that most of these newspapers are owned by News Corp (the largest print news publisher in the English-speaking world) or Fairfax Media (Australia's oldest and second-largest newspaper publisher). But virtually ignored is the role of newspapers and news websites that are locally owned and which, in their distribution areas, generally exert a greater impact than their Fairfax or News Corp competitors on the articulation of localism. Future analysis of the role of these truly local newspapers - in Perth's case the locally-owned Herald Publishing and The Post local newspaper groups - would help paint a clearer picture of how well local news is travelling in Australia.

In a recent article that stands out in Australian journalism studies for applying sense of place theory to journalistic practice, Hess \& Waller (2014, p. 121) argue that employing the

152 PACIFIC JOURNALISM REVIEW 21(1) 2015 
term 'community' to describe such 'small commercial news outlets that have geography as their primary characteristic' is problematic because the word 'community' overshadows the importance of geography. They advance instead the concept of 'geo-social journalism' as a framework for better 'understanding how these news outlets and audiences connect via the notion of "sense of place". While arguing that the importance of geography should not be discounted in understanding small newspapers, they acknowledge that a 'journalist's "place" in the journalistic field is a strong factor in the construction of news' (p. 126). It is this level of place-based articulation - where journalists imagine their own place and the place of others in the field of journalism - which we discuss next.

\section{Sense of place, and habitus}

By adding an inside perspective, critical reflexivity is seen as a means of enriching approaches to journalism studies that have examined the profession from the outside (Mason, 2014, p. 158). One way to employ critical reflexivity, or critical self-awareness in the practice, is through "self work" where individuals come to a conscious understanding of their dispositions' (Bourdieu \& Wacquant, cited in Mason, 2014, p. 167). Because the dispositions of habitus shape practice and position, journalists may also seek and gain self-awareness through identifying where the self is located within a particular set of power relations and structures - in Bourdieu's term, within a 'field' (Bourdieu, 2005). As habitus evolves, the practices and experiences that are shaped by and shape habitus also evolve. Self-work makes this process of change conscious, therefore giving the practitioner more awareness and agency, and more conscious control over their practice.

It was predominantly this self work that ACE aimed to engender among students, and it was the dispositions of habitus, and concerns about representation, that were predominantly addressed in student feedback. Most of the students found that through this process they engaged more genuinely with interviewees, as opposed to employing story extraction techniques to which they had previously become accustomed. Students also began to deconstruct their own colonised understandings of self and other, developing a 'sense of belonging within their host communities' (Stachowski \& Mahan, 1998, p. 159) that would lead to critical self-reflection and to greater understanding and appreciation of Perth's Indigenous people. This is illustrated in the students' comments:

When writing stories usually you probably just phone people up and there is a certain element of harassment (laughs), but with [ACE] we did build relationships ... Yeah, I [recommend] just doing the research but not research using Google kind of thing, doing research by really speaking to different people. (Student 1)

Beyond considerations of sourcing technique, ACE prompted the students to consider their philosophy of - and future in — journalism, for example: 
I don't really like to harass people and bombard them ... [I] definitely would recommend this approach of giving people your time, rather than just instead of just wanting [their answers] and [delivering] what you'd want ... I guess for me personally that kind of the stereotype of what a journalist is really isn't for me ... I think, to be honest, before I started [ACE] I was kind of set that I didn't really want to go into journalism when I finished my degree, so I think it has changed a little bit. (Student 1)

As the concept of habitus enabled students to become more aware of their practice and how it could evolve, habitus has also assisted us to conceptualise the experiences and interpret the data arising from this study.

Bourdieu (1989, p.19) draws connections between habitus and the notion of place, stating that habitus "implies a "sense of one's place" but also a "sense of the place of others". Expanding upon the link between habitus and place in a book of collected works, Habitus: A Sense of Place, to which Bourdieu contributed a chapter, Hillier and Rooksby (2005, p. 21) conceptualise habitus as 'an embodied, as well as a cognitive, sense of place'. They assert that Hirst, another contributor to the book, 'demonstrates the importance of [the concept of] exclusion to [the workings of] habitus, and in particular to a sense of the other's place' (p. 21).

When applied to the field of journalism, this link between habitus and sense of place reconceptualises the waning 'where?' question of journalistic investigation as the main question (that is, 'Where do I/they fit?') that needs to be answered when journalists consider their place and the place of others in their field. Student feedback provided evidence that the Bourdieusian imperative of considering the place of others had been enacted, in relation, but not limited, to, Indigenous people:

I think there's a real lack of cultural awareness in a lot of areas ... There's just some terrible stereotypes, I think ... The media play a huge part in the way Aboriginal people are represented. (Student 1)

[ACE] definitely made me more culturally aware, not even just with Indigenous people, just with everyone. (Student 2)

All journalist students should have to do [ACE] ... There just needs to be some sort of cultural understanding. Because it's not just about Aboriginal Australians. It makes you rethink your attitudes towards every other race that you have prejudice against. (Student 4)

In helping journalists reimagine the sense of their place and the place of others, the extension of 'where?' from geographic space (that is, the context in which it is normally understood) to imagined place repositions the question of 'where' back to the core of the journalistic profession. In relation to media voice, 'where?' can also be conceived as a question that Indigenous people might ask when considering how they engage with the media (that is, 'Where do I fit?'). Observations made by community partners at the end- 
of-semester showcase helped illustrate this point. One community partner commented on the stance his group had taken on racist reporting in a recent publication. In relation to a story produced by an ACE student about the racist coverage, the community partner explained: "It was great to have some, you know, real competent journalist students to follow through and do some really good quality articles about that".

An Indigenous participant from another community partner organisation spoke about a video produced by ACE screen arts students. Her comments reflected the feedback from all partner organisations:

\begin{abstract}
Well, I got really sick half way through and ended up in a hospital. So, I actually didn't lose any weight [as part of a healthy eating program about which the student video was produced]. But I actually did give up smoking [applause]. And, so the students actually then turned that into a community message which I thought was just absolutely amazing that, instead of focusing on one thing, they used their own initiative to say: 'Well, what can we do to make this a bigger thing?', and that really impressed me from a bunch of young people that they could actually do that ... Hopefully we can see more community messages that's gonna help our mob, because I think that's really important too that basically you've got the resources and we've got the knowledge and let's get together and actually make something bigger, 'cause I think this is the beginning of a new story.'
\end{abstract}

Each of the 10 feature stories produced by journalism students, for a new Aboriginal affairs round that was set up on the InkWire website, was an integral part of ACE. This helped our community partners establish a greater media voice. The new reporting round also helped articulate a more inclusive sense of Perth as a place. Since the foundation of ACE in 2013, the new reporting round has provided a locus for more Indigenous affairs stories from students in other journalism units who have been encouraged and guided by the existing exemplar stories. With the second and third iterations of ACE having concluded in the first teaching semesters of 2014 and 2015, multiple stories were added to the InkWire Aboriginal affairs round. A stand-alone 'Aboriginal Community Engagement' page (inkwirenews.com.au/ace-2015/) was produced in 2015 to showcase the work of that year's students, and to facilitate entry of the stories as a cohesive publication in the 'Best Publication' category of the national student journalism awards run by the Journalism Education and Research Association of Australia.

\title{
Closing comments
}

Reporting from a project in which journalism students collaborated with Noongar community organisations, we have argued in this paper that an understanding of Indigenous Australians' profound connection to place can inform journalists about the underlying character of places about which they report. It is hoped that exposing students to a deeper, richer mode of reporting will: 
- increase the likelihood of more specific stories and better Indigenous affairs stories;

- inform the journalistic practices of students, whether or not they choose to follow an Indigenous affairs reporting path; and

- serve as a prototype for forms of work integrated learning that position people and place back at the centre of journalism.

We have suggested that genuine engagement with the ancient, place-based culture of Australia's Indigenous people can do much to revive the 'where?' question of journalistic investigation. We have illustrated this revival in practice, drawing examples from the ACE project that led students to produce journalistic stories that contributed to a more inclusive articulation of Perth as a place.

Our experience is such that once students' consideration extends to the level of habitus - dispositions and position - their engagement with Indigenous people adds further significance and relevance to the question of 'where?' In our case this was achieved through the profound transformation of students' sense of their own place and the place of others in the field of journalism. Further, at this level of reflection, 'where?' was shown to be equally significant for participating Indigenous people, who achieved a greater sense of how they might negotiate a place in the media. Through this process we have found that Indigenous people can see the potential to find a voice through which they might achieve fairer media representation and be able to participate on an equitable basis.

\section{References}

Australian Bureau of Statistics (2012, March 30). 3218.0 Regional Population Growth, Australia.

Australian Bureau of Statistics. (2013). Estimates of Aboriginal and Torres Strait Islander Australians, June 2011. Retrieved on August 18, 2015, from www.abs.gov.au/ausstats/abs@.nsf/ $\mathrm{mf} / 3238.0 .55 .001$

Australian Bureau of Statistics. (2014, March 3). Feature article: Capital cities: past, present and future.

Barnett, C. (2014, November 1). Agreement finalised in SW Aboriginal settlement. Media statement. Retrieved on August 18, 2015, from www.mediastatements.wa.gov.au/Pages/Barnett/2014/11/ Agreement-finalised-in-SW-Aboriginal-settlement.aspx

Barnett, C. (2015, March 30). Noongars vote to accept historic offer. Media statement. Retrieved on August 18, 2015, from www.mediastatements.wa.gov.au/Pages/Barnett/2015/03/Noongarsvote-to-accept-historic-offer.aspx

Barnett, C. \& Mischin, A. (2013, July 6). Noongar people recognised in historic offer. Media statement. Retrieved on August 18, 2015, from www.mediastatements.wa.gov.au/Pages/Barnett/2013/07/Noongar-people-recognised-in-historic-offer.aspx

Bartleet, B-L., Bennett, D., Power, A., \& Sunderland, N. (2014). Enhancing Indigenous content in arts curricula through service learning with Indigenous communities. Sydney: Australian Government Office for Learning and Teaching.

Bartleet, B-L. \& Carfoot, C. (2013). Desert harmony: Stories of collaboration between Indigenous musicians and university students. In J. McLaughlin \& Z. Marhea (Eds.), The International

156 PACIFIC JOURNALISM REVIEW 21(1) 2015 
Education Journal: Comparative Perspectives. Special Issue: Global 21st Century Professionals: Developing capability to work with Indigenous and other Traditionally-Oriented Peoples, 12(1), 180-196.

Bennell v Western Australia. (2006, September, 19). Federal Court of Australia 1243. Retrieved on August 18, 2015, from www.austlii.edu.au/cgi-bin/sinodisp/au/cases/cth/FCA/2006/1243. html? stem $=0$ \&synonyms $=0$ \&query $=$ title $($ bennell $\% 20)$

Birrell, C.L. (2006). Meeting country: deep engagement with place and indigenous culture. Unpublished doctoral thesis, University of Western Sydney, New South Wales, Australia.

Bodney v Bennell (2008, April 23). Federal Court of Australia-Full Court 63. Retrieved on 18 August 2015, from www.austlii.edu.au/cgi-bin/sinodisp/au/cases/cth/FCAFC/2008/63.html? stem $=0 \&$ synonyms $=0$ \& query $=$ title $($ Bennell $\% 20)$

Bourdieu, P. (1989). Social space and symbolic power. Sociological Theory, 7(1), 14-25.

Bourdieu, P. (2005). The political field, the social science field, and the journalistic field. In R. Benson \& E. Neveu (Eds.), Bourdieu and the journalistic field (pp. 29-47). Cambridge, UK: Polity Press.

Bourdieu, P. \& Wacquant, L. J. D. (1992). An invitation to reflexive sociology. Cam- bridge, UK: Polity Press.

Buchanan, C. M. (2009). A changing sense of place in Canadian daily newspapers: 1894-2005. Unpublished doctoral thesis, M.J. Carleton University, Ottawa, Ontario, Canada.

Cass, P. (2002). Baptism of fire: How journalism students from the University of the South Pacific covered the Speight putsch and its aftermath. Round Table: The Commonwealth Journal of International Affairs. 366, 559-574.

Cho, M. (2006). Artistically serving: A study of the Lake County's arts-based service learning program. Unpublished doctoral dissertation, Florida State University, USA.

Collard, L., Goodchild, B. \& Marinova, D. (2011). Understanding place names in Southwest Australia. State of Australian Cities Conference, Nov 29-Dec 2 2011. Melbourne, Vic.: Australian City and Regional Network (ACRN).

Cox, S. L. (2012). 'Whose City/Whose Fremantle?': Reconceptualising space for an open politics of place. Unpublished doctoral thesis, Curtin University, Perth, Western Australia.

Cronin, R. (2013, October 4). Panel discussion after Jonathan Holmes lecture, Reflections of a media watcher. Curtin University, Perth, Western Australia.

Cullen, T. (2010). Student journalists learn about Aboriginal communities and culture in Western Australia. Asia Pacific Media Educator, 20, 153-162.

Department of Aboriginal Affairs (2013, May 27). Facts at a glance-Aboriginal demographics. Retrieved on August 18, 2015, from http://web.archive.org/web/20150309071333/http://www. daa.wa.gov.au/Documents/Information/Facts\%20at\%20a\%20glance\%20demographics.pdf

Donovan, J. D., Wilkes, E., Fielder, L. \& Jalleh, G. (2013). The publication of Australian Press Council Adjudication 1468: a failure to meet 'due prominence' requirements. Journal of Public Affairs, 13(1), 23-32.

Eyler, J. \& Giles, D. (1999). Where's the learning in service learning? San Francisco, CA: Jossey-Bass.

Fisk, R. (2014, February 2). Using 'generic' illustrations in news stories dishonours the dead and distorts the truth. Retrieved on August 18, 2015, from www.independent.co.uk/voices/ comment/robert-fisk-using-generic-illustrations-in-news-stories-dishonours-the-dead-anddistorts-the-truth-9102466.html

Forrest, S. (2014, April 14). Statement made to students and academic staff, and recorded by the authors, during ACE project field trip to site of Pinjarra Massacre.

Franklin, B. \& Murphy, D. (1991). What news?: The market, politics and the local press. London. Routledge. 
Funk, M. (2012). Imagined commodities? Analyzing local identity and place in American community newspaper website banners. New Media \& Society, 15(4), 574-595.

Furco, A. (1996). Service-learning: A balanced approach to experiential education. Expanding boundaries: Serving and learning, 1, 1-6.

Giroux, H. (1992). Post-colonial ruptures and democratic possibilities: Multiculturalism as antiracist pedagogy. Cultural Critique, 21(Spring), 5-39.

Glaskin, K. (2012). Anatomies of relatedness: Considering personhood in Aboriginal Australia, American Anthropologist, 114(2), 297-308.

Gorringe, S. (2010, September). Honouring our strengths: Moving forward. Keynote Address presented at the 2010 Annual SPERA Conference. Stronger Smarter Institute, Queensland University of Technology. Queensland: University of the Sunshine Coast.

Griffin, G. (1999). Local journalist makes good: Cultural geography and contemporary journalism. Australian Journalism Review, 21(1), 17-36.

Guest, A. (2006, September 22). Noongar decision has implications for public land access: Philip Ruddock. Retrieved on August 18, 2015, from www.abc.net.au/am/content/2006/s1746137.htm

Guffey, J. (2008, July). Embracing an Indigenous understanding of service-learning. Keynote address presented at the NWIC Second Summit on Indigenous Service-learning, North West Indian College, Bellingham, WA, USA. Retrieved on August 18, 2015, frow.yumpu.com/en/ document/view/6868176/embracing-an-indigenous-understanding-of-service-learning

Haig-Brown, C. (2001). Continuing collaborative knowledge production: Knowing when, where, how and why. Journal of Intercultural Studies, 22(1), 19-32

Harcup, T. (1998). There is no alternative: the demise of the alternative local newspaper. In B. Franklin \& D. Murphy (Eds.), Making the local news: Local journalism in context (pp. 105116). London: Routledge.

Hartley, J. (2003). 'Their own media in their own language'. In C. Lumby \& E. Probyn (Eds.), Remote control: new media, new ethics (pp. 42-66). Cambridge: Cambridge University Press.

Hess, K. \& Waller, L. (2014). Geo-social journalism. Journalism Practice, 8(2), 121-136.

Hillier, J. \& Rooksby, E. (Eds.). (2005). Habitus: A Sense of Place (Second Edition). Aldershot, England: Ashgate.

Hirst, P. (2005). Politics: Territorial or non-territorial? In J. Hillier and E. Rooksby (Eds.), Habitus: A sense of place (2nd ed., pp. 68-82). Aldershot, England: Ashgate.

Hughes-Hallett, D. (2010). Indigenous history of the Swan and Canning rivers, A project with the Swan River Trust. Curtin University student work placement. Retrieved on August 18, 2015, from www.swanrivertrust.wa.gov.au/docs/fact-sheets/indigenous-history-of-the-swanand-canning-rivers.pdf

Janesick, V. (2000). The choreography of qualitative research design: Minuets, improvisations, and crystallization. In N. K. Denzin \& Y. S. Lincoln (Eds.), Handbook of qualitative research (2nd ed., pp. 379-400). Thousand Oaks, CA: Sage.

Jay, J., Moss, L., \& Cherednichenko, B. (2009). The Aboriginal practical experience and its impact on pre-service teachers: Decisions about living and working in remote indigenous communities in Australia. Education in Rural Australia, 19(3), 35-43.

Johnston, M. \& Bishop, R. (2013). Noongar Dandjoo: A work integrated learning case study. Asia Pacific Media Educator, 22(2), 165-177.

Johnston, M., Bennett, D.E., Mason, B., and Thomson, C. (2015). Finding common ground: Combining participatory action research and critical service-learning to guide and manage projects with Aboriginal communities. In B-L. Bartleet, D. Bennett, A. Power, N. Sunderland (Eds.), Engaging first peoples in arts-based service learning - towards respectful and mutually beneficial educational practices. Switzerland: Springer. In press.

158 PACIFIC JOURNALISM REVIEW 21(1) 2015 
Kahne, J., Westheimer, J., \& Rogers, B. (2000). Service learning and citizenship: Directions for research. Michigan Journal of Community Service Learning, 7, 15-24.

Kerr, T., \& Cox, S. (2013). Noongar tent embassy - A report on Perth media. Perth. Ctrl-Z Press. Littlepage, L., Gazley, B., \& Bennett, T. A. (2012). Service learning from the supply side: Community capacity to engage students. Nonprofit Management and Leadership, 22(3), 305-320.

Mackinlay, E. (2008). Making space as white music educators for Indigenous Australian holders of song, dance and performance knowledge: The centrality of relationship as pedagogy. Australian Journal of Music Education, 1, 2-6.

Mackinlay, E., \& Dunbar-Hall, P. (2003). Historical and dialectical perspectives on the teaching of Aboriginal and Torres Strait Islander musics in the Australian education system. Australian Journal of Indigenous Education, 32, 29-40.

McCarthy, F. E. (2003). Service learning triangle: Key concepts, partners, relationships. Tokyo, Japan: International Christian University.

Mason, B. (2014). Journalism practice and critical reflexivity: A death in custody interview, Pacific Journalism Review, 20(1), 158-179.

Meyrowitz, J. (1985). No sense of place: The impact of electronic media on social behavior. New York: Oxford University Press.

Molnar, M. (2010). Arts-based service learning: A curriculum for connecting students to their community. Unpublished masters thesis. Retrieved from UMI. (No. 1483646).

Naidoo, L. (2011). Beyond institutional walls: Literacy support for Indigenous students at a remote high school in the Northern Territory. Literacy Learning: the Middle Years, 19(3), 9-18.

National Indigenous Higher Education Network. (2009). Report to members of the United Nations Permanent Forum on Indigenous Issues, Supporting Intervention for Agenda ITEM 6 - Comprehensive Dialogue with UN Agencies. Eighth Session UN Headquarters, New York, 18 - 29 May 2009. National Native Title Tribunal. (2006, October). Talking Western Australia, National Native Title Tribunal State E-News, Issue 8. Retrieved on August 18, 2015, from http:// web.archive.org/web/20090520083301/http://www.nntt.gov.au/News-and-Communications/ Newsletters/State-E-Newsletters-Archive/Documents/State\%20e-newsletter\%20TNT\%20 WA\%20special\%20edition\%200ct\%202006.pdf

Newsome, J. (1999). Indigenous music in the academy: Whose music? Whose identity? in G. Bloustein (Ed.), Musical visions: Selected conference proceedings from 6th National Australian/New Zealand IASPM and inaugural Arnhem Land Performance Conference (pp. 95-103). Adelaide, Australia: Wakefield Press.

Pauly, J. J., \& Eckert, M. (2002). The myth of 'the local' in American journalism. Journalism and Mass Communication Quarterly, 79(2), 310-326.

Peatling, S. (2006, September 22). Fear of native title land grab in cities. Retrieved on August 18, 2015, from www.smh.com.au/news/national/fear-of-native-title-land-grab-incities/2006/09/21/1158431843986.html

Plater, D. (1993). Aboriginal people and the media: reporting Aboriginal affairs, Aboriginal justice issues-proceedings of a conference held 23-25 June 1992, McKillop, S. (Ed.), Australian Institute of Criminology.

Plumwood, V. (2005). Belonging, naming and decolonisation. In Hillier, J. \& Rooksby, E. (Eds.), Habitus: A sense of place. (2nd ed., pp. 371-391). Aldershot, England: Ashgate Publishing.

Rapoport, A. (1972). Australian Aborigines and the definition of place. Nature and Human nature, (10). Deakin University.

Richardson, N. (2012). The virtues of localism in the digital age. In M.Ricketson (Ed.) Australian Journalism Today (pp.123-139). South Yarra: Palgrave Macmillan.

Robie, D. (2001). Frontline reporters: A students' internet coup. Pacific Journalism Review, 7, 47-56.

PACIFIC JOURNALISM REVIEW 21 (1) 2015159 
Robie, D. (2010). Pacific freedom of the press: Case studies in independent campus-based media models. Pacific Journalism Review, 16(2), 99-126.

Robinson, D. B., \& Meyer, M. (2012). Health education and interactive drama: Findings from a service learning project. Health Education Journal, 71(2), 219-228.

Rooney, D. (2003). Rethinking the journalism curriculum in PNG. Asia Pacific Media Educator, 14, 76-91.

Royal Commission into Aboriginal Deaths in Custody. (1991). Regional report of inquiry into underlying issues in Western Australia. Retrieved on August 18, 2015, from www.austlii.edu. $\mathrm{au} / \mathrm{au} / \mathrm{other} /$ IndigLRes/rciadic/regional/wa_underlying/

Siebenaler, D. (2005). Music and service learning: A case study. Journal of Music Teacher Education, 15, 23-30.

Soja, E. W. (2000). Postmetropolis: Critical studies of cities and regions. Oxford, UK: Blackwell.

Somerville, M., \& Perkins, T. (2003). Border work in the contact zone: Thinking indigenous/nonindigenous collaboration spatially. Journal of Intercultural Studies, 24(3), 253-266.

South West Land and Sea Council. Retrieved August 18, 2015, from www.noongarculture.org.au/

Stachowski, J. J., \& Mahan, J. M. (1998). Cross-cultural field placements: Student teachers learning from schools and communities, Theory into Practice, 37 (2), 155-162.

Stasiuk, G. (2015). Wadjemup: Rottnest Island as black prison and white playground Unpublished doctoral exegesis, Murdoch University, Perth, Western Australia.

Stewart, H., Meadows, M., Bowman, L., van Vuuren, K., \& Mulligan, P. (2010). Indigenous voice: A work-integrated learning case study in journalism education. Australian Journalism Review, 32(2), 59-72.

Tacchi, J., Slater, D., \& Hearn, G. (2003). Ethnographic action research. New Delhi: United Nations Educational, Scientific and Cultural Organisation (UNESCO).

Thomson, C. (2009, November 25). Government shelves Perth native title litigation. Retrieved on August 18, 2015, from www.watoday.com.au/wa-news/government-shelves-perth-nativetitle-litigation-20091124-jflp.html

Universities Australia. (2011, October). National best practice framework for Indigenous cultural competency in Australian universities.

Walrus Research. (2006). A sense of place: The values of localism in public radio. Produced for Public Radio Program Directors Association. Hamilton, New York.

Winter, A., Wiseman, J., \& Muirhead, B. (2006). University-community engagement in Australia: Practice, policy and public good. Education, Citizenship and Social Justice, 1, 211-230.

Chris Thomson is a lecturer at Curtin University where he teaches online journalism, photojournalism and Indigenous affairs reporting. In 2010, Chris set up Australia's first independent, metropolitan news website which he still operates. Before that he was a journalist and national columnist with the Fairfax company, a reporter for an independent Perth newspaper group, and a bilateral trade negotiator and policy and programme manager with the Australian government and later a national industry association. Chris has postgraduate degrees in urban planning, creative writing, and journalism. His journalism has appeared in many national newspapers and magazines.

chris.thomson@curtin.edu.au

Dawn Bennett is John Curtin Distinguished Professor and director of the Creative Workforce Initiative with Curtin University. Her recent research has focused on identity development, employability, graduate transition and creative labour markets, with a particular focus on the impact of identity

160 PACIFIC JOURNALISM REVIEW 21(1) 2015 
development on higher education learning. An active violist, Dawn serves numerous editorial boards and she convenes the Australian Learning and Teaching Fellows' network. She is on the board of directors for the International Society for Music Education and the Music Council of Australia, serves as a commissioner with the ISME Commission for Education of the Professional Musician, and chairs the Curtin Academy.

dawn.bennett@curtin.edu.au

Dr Michelle Johnston lectures in Film, Television and Screen Arts at Curtin University where she has worked since 2000. She specialises in multi-cam television production and has nearly 20 years of experience working in media and the television industry. Her PhD project focused on Indigenous community media, action research and cross-cultural collaboration. Michelle has produced five series of an Aboriginal community television program called Noongar Dandjoo and is currently involved in a service-learning programme for Curtin media students working with Aboriginal community groups.

m.johnston@exchange.curtin.edu.au

Dr Bonita Mason is a writer, award-winning freelance journalist and journalism lecturer at Curtin University, where she teaches first-year journalism, feature writing and specialist Indigenous reporting. Her PhD project critiqued mainstream media coverage of Aboriginal deaths in custody, and advocates reflective journalism practice and reflexivity in journalism research. Bonita has also worked as a policy adviser and speechwriter for government, and as a media and policy adviser for Aboriginal land rights and other organisations in the Kimberley and nationally.

bonita.mason@curtin.edu.au

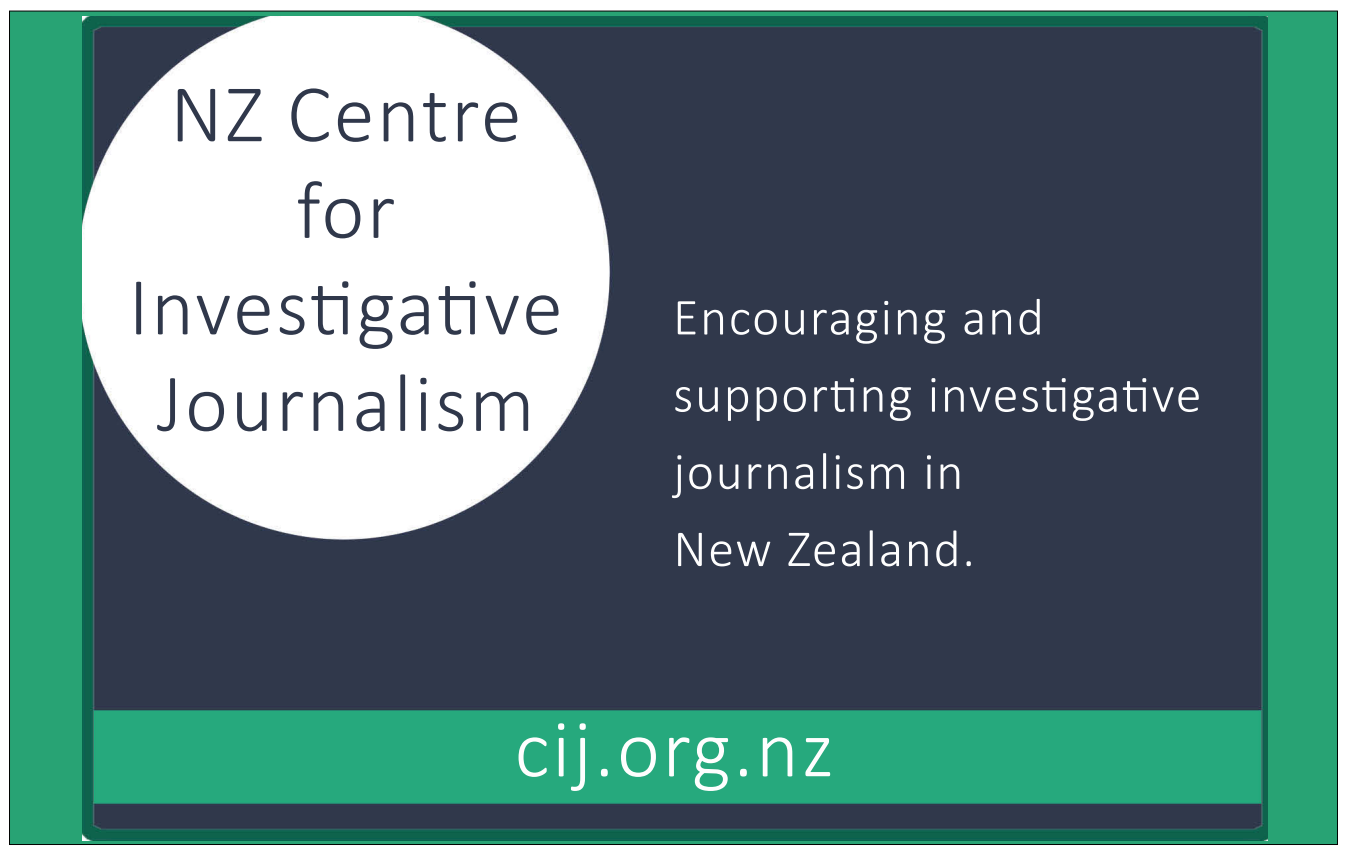

PACIFIC JOURNALISM REVIEW 21 (1) 2015161 